\title{
㚘粘膜癌切除術における顎下腺管グラフトを 用いた耳下腺管再建
}

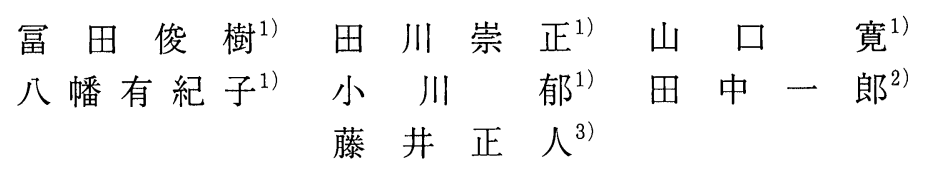

要旨 : 煩粘膜癌の手術において多くの場合, 耳下腺管は結紮される。我々は, 切除した耳下腺管を顎下 腺管グラフトにより再建したので報告する。症例は煩粘膜癌（T3N1M0）である。開口部から約 $3 \mathrm{~cm}$ の耳下腺管を腫瘍と合併切除した後, 頸部郭清術で採取した顎下腺管を用いて耳下腺管断端と新開口部 をバイパスし前腕皮弁にてパッチ再建した。術後照射を行った影響もあり顎下腺管グラフトの長期開存 は得られなかった。しかし術後の耳下腺腫脹や唾液癭を回避できたことから本術式は有用であると思わ れた。本術式は低侵襲かつ簡便であり, 術前の唾液分泌が正常で耳下腺管開口部付近を切除し頸部郭清 術を行う口腔癌症例に対して適応があると思われた。

キーワード : 㚘粘膜癌, 耳下腺管, 顎下腺管, グラフト, 再建

Summary Parotid duct repair using Wharton's duct graft in radical surgery for buccal mucosa carcinoma:

Toshiki Tomita, Takamasa Tagawa, Hiroshi Yamaguchi, Yukiko Yahata, Kaoru Ogawa, Ichiro Tanaka and Masato Fujii. Department of Otolaryngology, Keio University School of Medicine

A parotid duct is frequently cut and simply ligated in radical surgery for buccal mucosa carcinoma. We performed reconstruction of the salivary duct by microsurgical repair using a submandibular duct graft in a case of buccal mucosa carcinoma (T3N1MO). We made a bypass between the new orifice and the cut end of the parotid duct using a submandibular duct graft which was obtained by selective neck dissection (level I to II). The defect after resection of the buccal mucosa was covered with the free radial forearm flap. The reconstructed submandibular duct graft collapsed after the postoperative radiotherapy. The function of the parotid gland could not be preserved; however, this method was useful because the postoperative complications such as salivary fistula or swelling of the parotid gland could be avoided. This method is simple and minimally invasive. This method should be indicated in the case of $\mathrm{N}$ positive oral carcinoma in which parotid function is normal preoperatively. A case of parotid duct repair using a submandibular duct graft is reported.

Key words : duccal mucosa carcinoma, parotid duct, Wharton's duct, graft, reconstruction

\footnotetext{
1) 慶應義塾大学医学部耳鼻咽喉科

2) 慶應義熟大学医学部形成外科

3) 国立病院東京医療センター耳鼻咽喉科
} 
はじめに

口腔癌手術において耳下腺管が開口部を含めて 合併切除される際, 耳下腺管の切除断端は結紮さ れることが多い。癌の浸潤や術前照射により耳下 腺機能がすでに低下・廃絶している場合や，頸部 郭清術の際に耳下腺被膜を損傷しない場合には耳 下腺管は結紮して問題ない。しかし耳下腺機能が 正常で頸部郭清術において耳下腺被膜が損傷され る場合には唾液瘦の可能性が高く, 特に遊離皮弁 再建が行われる場合には吻合血管の破綻などによ る皮弁の合併症が懸念される。我々は以前, 口腔 底癌の煩粘膜浸潤例に対し拡大切除・頸部郭清術 を施行し耳下腺管を結紮したところ, 術後に頸部 の唾液瘦をきたした経験がある。同症例ではドレ ナージと圧迫による保存的治療を行ったが改善し ないため耳下腺全摘術を余儀なくされた。耳下腺 管断端を近傍の粘膜に縫い付けることが可能であ れば良いが, 実際には多くの場合，耳下腺管は深 部で切断され粘膜に縫合することは不可能である。 このような場合にはグラフトを用いて耳下腺管を 再建することが望ましいと思われる。

今回, 我々は, 開口部から約 $3 \mathrm{~cm}$ の耳下腺管 を煩粘膜癌と合併切除し頸部郭清で採取された顎 下腺管をグラフトとして用いて耳下腺管を再建し たので報告する。

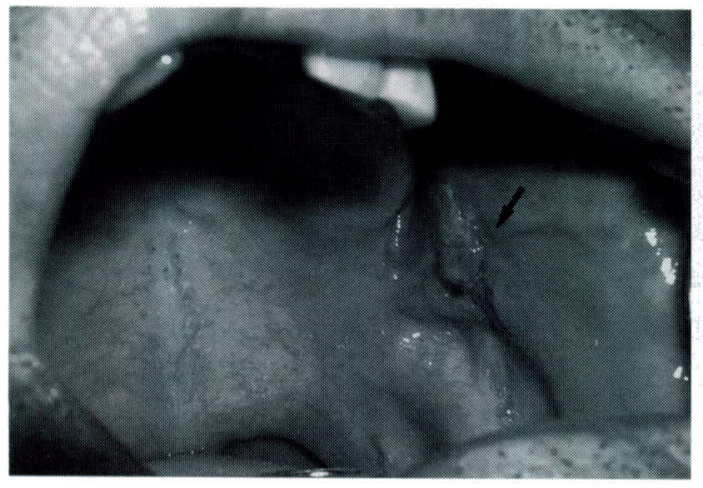

図 1 初診時所見

左煩粘膜に径 $2 \mathrm{~cm}$ 大の表面不整な腫瘍を認め，耳 下腺管開口部は腫崵の約 $7 \mathrm{~mm}$ 前方に位置してい た (矢印)。

\section{症例}

患者 : 69 歳, 男性

主訴：左㚘粘膜痛

既往歴および家族歴 : 特記すべきことなし

現病歴：平成 15 年 4 月頃から頪粘膜の疼痛を 認め, 徐々に増悪したため平成 15 年 7 月当科紹 介受診した。

現症 : 左㚘粘膜に径 $2 \mathrm{~cm}$ 大の表面不整な腫瘍 を認めた。臼後三角に一部浸潤していたが開口障 害は認めなかった。耳下腺管開口部は腫瘍端の約 $7 \mathrm{~mm}$ 前方に位置し, 唾液の分泌が認められた (図 1)。径 $1.5 \mathrm{~cm}$ 大の左顎下リンパ節を触知した。 MRI 所見（図 2）：ガドリニウム造影 T1 強調 画像では左㚘粘膜に前後 $4.5 \mathrm{~cm}$, 上下 $3 \mathrm{~cm}$, 深さ $1.9 \mathrm{~cm}$ の辺縁不整な高信号域を認めた。㚘筋への 浸潤が疑われたが内側翼突筋への浸潤は認めなかっ た。
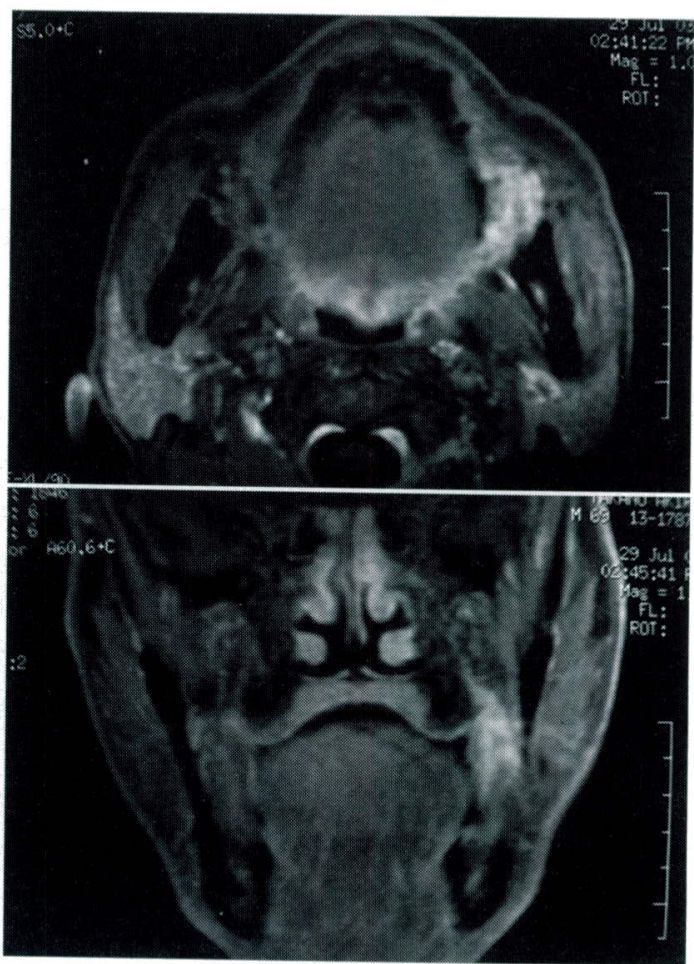

図 2 MRI (上: 軸位断, 下 : 冠状断) ガドリニウム造影 $\mathrm{T} 1$ 強調画像では左㚘粘膜に前後 $4.5 \mathrm{~cm}$, 上下 $3 \mathrm{~cm}$, 深さ $1.9 \mathrm{~cm}$ の辺縁不整な高信 号域を認めた。㚘筋への浸潤が疑われたが内側翼突 筋への浸潤は認めなかった。 


\section{頭顓部外科 $14(2) ： 133 \sim 137,2004$}

経過：生検の病理組織診断は中分化型扁平上皮 癌で, T3N1MO，III期と診断し，平成 15 年7月 31 日に㚘粘膜切除・左選択的頸部郭清術（レベル I 〜 III ) · 左前腕皮弁による再建術を行った。

手術所見：頸部郭清術を行い, 顎下腺管を可能 な限り口腔底方向に追跡し約 $4 \mathrm{~cm}$ のグラフトを 採取した。この際，ピオクタニンで末梢端をマー キングした。下口唇正中切開に続いて歯肉煩粘膜 移行部を後方に切開し, 腫瘍を明視下において粘 膜面で約 $2 \mathrm{~cm}$ のマージンを確保した。煩筋を切 除に含めて煩脂肪の層で切除をすすめ咬筋も部分 切除した。耳下腺管開口部からインジゴカルミン を注入・染色し, 切除の途中で耳下腺管を同定し

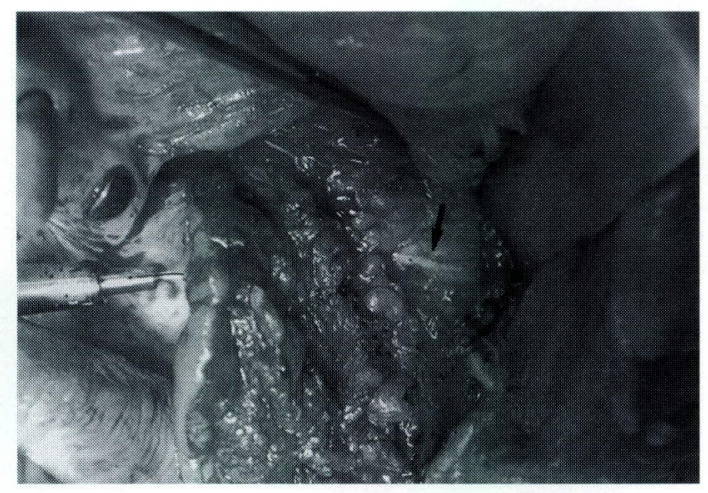

図 3 術中所見

耳下腺管開口部からインジゴカルミンを注入し染色 し切除の途中で耳下腺管を同定した（矢印）。

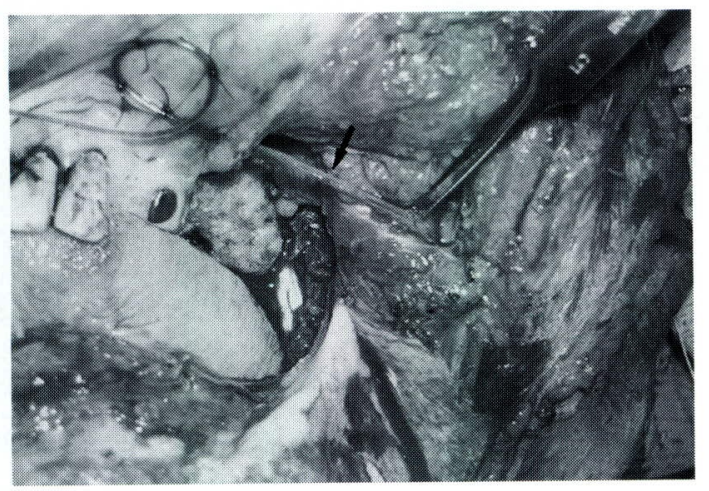

図 4 術中所見

小児用アトムチューブをステントにして顎下腺管グ ラフトを順行性に置き, グラフトを新開口部と耳下 腺管深部断端に吻合した (矢印)。
結紮切断した（図 3)。下顎骨，上顎骨は骨膜下に 剥離し, 内側翼突筋を一部含めて腫瘍を一塊切除 した。

採取した約 $4 \mathrm{~cm}$ 長の顎下腺管グラフトを順行 性に移植した。まず煩粘膜切除断端の頭側約 5 $\mathrm{mm}$ の位置に新開口部を作成した。小児用アトム チューブをステントにして顎下腺管グラフトを置 き, 耳下腺管深部断端とは顕微鏡下に9-0, 8-0 ナイロンによる結節縫合によって計 12 針で端端 吻合を行った。続いて末梢側では顎下腺管グラフ トの長軸方向に割を入れて口径を拡大した後, 切 開した新開口部煩粘膜と 9-0ナイロンにて計 10 針で吻合した（図 4)。顎下腺管グラフトにより再 建された耳下腺管を含む㚘粘膜欠損部は, 前腕皮 弁でパッチ状に被覆し再建した。両端を吻合した グラフトの上に前腕皮弁を置くと適切な緊張がか かってグラフトの位置は安定したため, グラフト 自体の縫合固定は不要であった（図 5)。顔面神経 煩枝は切断していたため煩皮膚を小切開してペン ローズドレーンを挿入し皮弁と皮膚の間に留置し た。摘出標本では耳下腺管開口部に癌の浸潤は認 めないものの癌先端部から $7 \mathrm{~mm}$ しか離れていな かった（図6）。

術後経過 : 術後ステントチューブから唾液の流 出を少量ずつ持続的に認め, 耳下腺の腫脹は認め なかった。経過は良好で経口摂取は10日目から 開始し術後 17 日目までステントチューブを留置 した。病理組織検査で後方深部が close margin

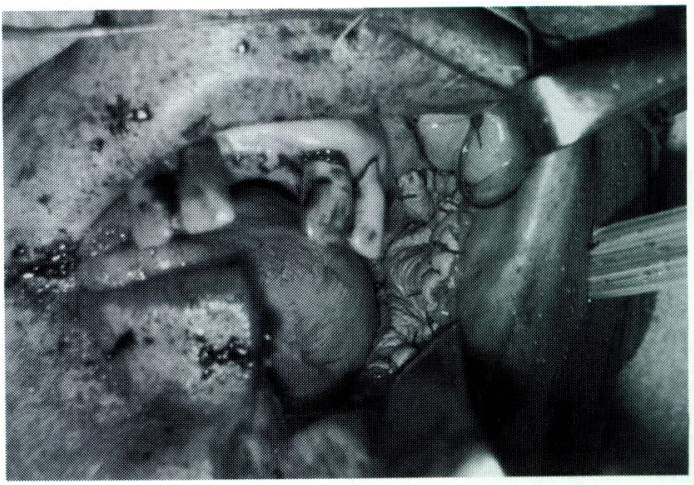

図 5 術中所見

㚘粘膜欠損部を前腕皮弁でパッチ状に被覆し再建した。 


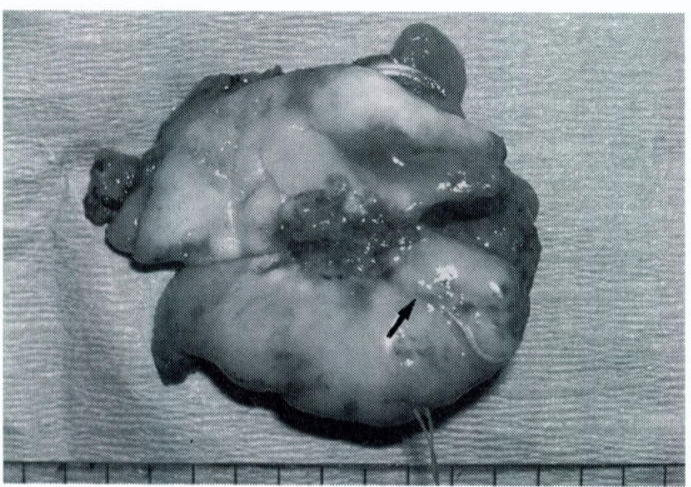

図 6 摘出標本

耳下腺管開口部（矢印）に癌の浸潤は認めない。糸 は前方である。

であったため術後 24 日目から照射を開始した。 照射途中までは唾液分泌を認めたが，60Gy の照 射終了時ごろから開口部を確認できなくなった。 12 月に施行した喠液腺シンチグラムでも集積を認 めず耳下腺機能は廃絶したと考えられた。

\section{考察}

㚘粘膜癌の手術における耳下腺管の処理に関す る報告は殆どない。早期癌に対し口内法で切除す る場合，可能な限り耳下腺開口部を造設するが耳 下腺管を結紮しても術後数日耳下腺の腫脹をきた すが問題にならないとされている ${ }^{1)}$ 。しかし耳下 腺管を結紮すると唾液腺は廃用性の萎縮をきたし その機能は廃絶する。もし耳下腺管の再建によっ て唾液腺機能が温存されれば術後の QOLを向上 させることができる。特に煩粘膜欠損を皮弁でパッ 千再建する場合には咀嚼機能障害を軽減させるた めにも意義深い試みであると思われる。

耳下腺管の修復・再建に関する報告は少なく, その多くは外傷に関連するものである。古くは北 村らが 12 例の耳下腺管手術の論文のなかで，2 例 のグラフトを報告している ${ }^{2)}$ 。1 例は奇形による 狭窄部を顎下腺管グラフトで再建しているが詳細 な手技や長期経過は不明である。また静脈グラフ トで再建した 1 例は閉塞をきたしたため静脈グラ フトは推奖できないと述べている。近年, 顕微鏡 手術の技術が耳下腺管の修復に応用され始めた。 顔面外傷による耳下腺管断裂部を 9-0 ナイロンで 顕微鏡下に修復した報告においては, 術後 1 年後
にシアログラムを施行し吻合部狭窄を認めるもの の開存を確認している3)。また顔面外傷による耳 下腺管欠損部に対して静脈グラフトを用いて修復 した報告では, 顕微鏡下に 9-0 ナイロンで吻合し ているが長期経過は不明である4)。静脈グラフト については疑問視されてきたが, 近年, 犬を用い た実験において静脈グラフト単独では閉塞してし まうことが確認された 静脈グラフト単独の場合やはり閉塞したが咬筋筋 膜で包むと開存し, さらにステントを留置すると より良いと報告されている ${ }^{6)}$ 。

我々が渉猟した限りでは煩粘膜癌を含めた口腔 癌手術において耳下腺管を修復したという報告は なかった。

今回グラフトを選択する際にまず静脈グラフト を検討したが, 文献的に長期開存は期待できずグ ラフト採取のために創部が増えることから選択し なかった。顎下腺管グラフトに着目した理由は, 粘液腺と漿液腺の違いはあるものの同じ唾液腺管 であり静脈グラフトに比べ生理的であることから 長期的な開存に期待できると考えたためである。 また壁の厚さ，管腔径の点で静脈グラフトより耳 下腺管にマッチし吻合も容易であると思われた。

一方, 顎下腺管グラフトの危険性, すなわちグ ラフトに癌細胞が付随する可能性を慎重に検討し た。まず本症例において顎下腺管は煩粘膜癌の原 発巣とは充分に離れており腫瘍の直接浸潤は無い と思われた。また術前の画像所見で転移が疑われ たリンパ節は顎下腺より外側にあり,リンパ行性 に転移した癌細胞も顎下腺が障壁になるため顎下 腺管近傍にまで転移する可能性は非常に低いと考 えられた。さらに本来の頸部郭清術の郭清範囲よ り内側前方の顎下腺管を採取するため安全である と判断した。術中所見として節外浸潤の可能性は 低くまた腫脹したリンパ節は顎下腺管と充分に離 れていたため予定通りグラフトを採取した。

具体的なグラフトの吻合手技については近年の 動物実験の報告を参考にした。ステントをグラフ ト及び耳下腺管の内腔に予め挿入した後に, 顕微 鏡下に 9-0ナイロン, 8-0 ナイロンの結節縫合を 行った。顎下腺管グラフトの壁の厚さ, 管腔径は 耳下腺管とほぼ等しく吻合は容易であった。また 煩粘膜に造設した新開口部とグラフトとの吻合も 
容易であった。ステントとして用いた小児用アト ムチューブの末梢端は口腔外に出し固定したが, 経口摂取を開始してからも特に問題を認めなかっ た。術後急性期において耳下腺の唾液分泌量は安 定しなかったためステントを 17 日間留置した。 ステントを可能な限り長期間留置した方が吻合部 狭窄を回避でき長期的な開存が期待できると考え た。

また本術式の利点としてグラフト採取が非侵襲 的であることが挙げられる。顎舌骨筋を内上方に 牽引し口腔底方向に顎下腺管を追跡するだけであ るので時間もかからず簡便である。この際，先に 舌神経を同定しておいて損傷しないように留意し た。またグラフト採取時には末梢端と中枢端を判 別できるようにマーキングすることがより生理的 な再建を行う上で重要であると思われた。

本症例では約 $3 \mathrm{~cm}$ 弱の耳下腺管の欠損を約 4 $\mathrm{cm}$ の顎下腺管グラフトで再建した。採取可能な 顎下腺管グラフトの長さは本症例においては約 4 $\mathrm{cm}$ であった。皮弁内に穴を開けグラフトを貫通 させると最短長で口腔内に導けると思われたが, 皮弁内血管の損傷を懸念し皮弁縫着部より離れた 煩粘膜に新開口部を造設し皮弁下にグラフトを置 いた。本症例においてグラフトの長さは過不足な かった。しかし切除範囲が広くグラフトの長さが 不足する場合には, 安全と考えられる部位で皮弁 を一部切開してグラフトを導くか静脈グラフトを インターポジションして移植するなど, 何らかの 対応策が必要である。

本症例においては残念ながらグラフトの長期的 な開存は得られなかった。閉塞をきたした原因と して 60Gy の術後照射による影響が大きいと思わ れる。患側耳下腺は照射野に含まれていたため, 耳下腺の線維化が生じて唾液分泌能が低下しグラ フトが廃用性萎縮をきたした可能性が考えられる。 またグラフト自体も照射野に含まれていたのでグ ラフトの繊維化が生じた可能性もある。

今回, 我々は耳下腺機能を温存する目的で本術 式を施行した。切除標本の margin が充分で頸部 転移が pN1であれば術後照射は行わない方針で あったが, 病理組織検査で close margin であっ たため術後照射は必要であると判断した。術後照 射を行わなければグラフトは長期開存し耳下腺機
能を温存し得た可能性があると考えている。

耳下腺機能を温存することはできなかったが， 術後急性期の耳下腺腫脹や唾液漏などの合併症を 回避できた点において本術式は有用であった。グ ラフトは使用せずアトムチューブなどを耳下腺管 切除断端に挿入し留置して唾液のドレナージを図 り合併症を回避する方法もあるが，これを抜去す る時期を判断することは難しい。本術式は術後急 性期の合併症を回避する目的だけでも試みられる べきである。

最後に, 本術式の適応をまとめると以下のよう に考えられる。耳下腺管開口部への癌浸潤を認め ず唾液分泌は正常であるが耳下腺管開口部付近を 切除する場合, また頸部郭清が必要であるが顎下 腺管への癌浸潤が否定できる場合である。採取可 能な顎下腺管グラフトの長さは約 $4 \mathrm{~cm}$ 前後であ り，切除範囲によっては移植する際に何らかの工 夫が必要となる。

\section{まとめ}

耳下腺機能を温存するために顎下腺管グラフト を用いて耳下腺管を再建した。術後照射を行った 影響もあり結果的にはグラフトの長期開存は得ら れなかった。しかしながら術後の耳下腺腫脹や唾 液漏は認めなかったことから本術式を施行した意 義はあったと思われた。本術式は低侵襲かつ簡便 であり，適応を選んで積極的に施行すべきと思わ れた。

\section{文献}

1) 羽田達正, 朝莶孝宏, 平野浩一: 口腔癌. 新癌の外 科一手術手技シリーズ 頭頸部癌 (林 隆一編), 21-40, メジカルビュー社, 東京, 2003.

2) Kitamura T, Togawa K : Surgery of Stensen's duct. Arch Otolaryngol $93: 189-193,1971$.

3) Hallock GG: Microsurgical repair of the parotid duct. Microsurgery $13: 243-246,1992$.

4) Heymans $O$, Nelissen $X$, Medot $M$ et al: Microsurgical repair of Stensen's duct using an interposition vein graft. $J$ Reconstr Microsurg 15 : 105-107, 1999.

5) Dumpis J, Feldmane L: Experimental microsurgery of salivary ducts in dogs. $\mathrm{J}$ Craniomaxillofac Surg 29:56-62, 2001.

6) Chudakov O, Ludchik T: Microsurgical repair of Stensen's and Wharton's ducts with autogenous venous grafts. An experimental study on dogs. Int J Oral Maxillofac Surg $28: 70-73,1999$. 